\title{
Metode Bayes Dan Ketidaksamaan Cramer-Rao Dalam Penaksiran Titik
}

\author{
Georgina M. Tinungki*
}

\begin{abstract}
Abstrak
Ketidaksamaan Cramer-Rao merupakan batas bawah dari variansi suatu penaksir tak bias. Suatu penaksir tak bias mempunyai variansi yang sama dengan batas bawah yang berarti bahwa penaksir tersebut mempunyai variansi terbaik dalam kumpulan besar dari penaksir.
\end{abstract}

Keywords: peluang bersyarat, penaksir tak bias, penaksir titik

\section{Pendahuluan}

Banyak metode penaksiran titik yang kita kenal, namun diantara metode-metode tersebut mempunyai keunggulan masing-masing dalam menaksir suatu parameter. Jika dalam suatu kasus dimana informasi yang tersedia, sering hanya sebagian saja tentang suatu gejala tertentu. Namun jika ingin mengetahui bagaimana hal ini mempengaruhi peluang yang diinginkan maka akan dibahas peluang bersyarat dan aturannya, dan sifat tambahan dari peluang. Kenyataannya suatu penaksir tak bias mempunyai variansi yang sama dengan batas bawah yang berarti bahwa penaksir tersebut mempunyai variansi terbaik (terkecil) dalam kumpulan besar dari penaksir. Namun tidak semua penaksir yang memenuhi syarat-syarat yang membuat ketidaksamaan itu benar, sehinga penulis mencoba untuk mengkaji lebih dalam metode penaksir titik tersebut.

\section{Landasan Teori} menunjukkan:

Peluang bersyarat, aturan dan sifat tambahan dari peluang berikut ini Frekwensi peluang $R(A)=\frac{n(A)}{n}$, untuk semua kejadian A, dimana banyaknya usaha yang dilakukan dinyatakan sebagai $R(A)$ dan bila n membesar $R(A)$ akan dekat ke $P(A)$ sehingga :

$$
P(A)=\lim _{n \rightarrow \infty} R(A)=\lim _{n \rightarrow \infty} \frac{n(A)}{n}
$$

Apabila terdapat $\mathrm{n}$ usaha yang tidak berkaitan dari usaha percobaan dan kemudian mengamati apakah kejadian A tertentu telah terjadi atau tidak, dan misalkan $\mathrm{n}(\mathrm{A})$ banyaknya $\mathrm{k}$ kali terjadi dalam $\mathrm{n}$ usaha, maka frekwensi relatif $\mathrm{A}$ dalam $\mathrm{n}$ usaha adalah $\mathrm{n}(\mathrm{A}) / \mathrm{n}$ yang dinyatakan dengan $\mathrm{R}(\mathrm{A})$. Jika ingin diketahui frekwensi relatif A jika $\mathrm{B}$ telah terjadi dalam usaha tadi (misalnya, ini mungkin diperlukan bila A kejadian "sakit

\footnotetext{
* Staf Pengajar pada Jurusan Matematika F.MIPA Universitas Hasanuddin Makassar
} 
kanker paru", B terjadi kejadian "merokok", dan diamati n orang). Sekarang misalkan B terjadi $\mathrm{n}(\mathrm{B})$ kali dari seluruh usaha, dan seringnya A terjadi dalam usaha (B telah terjadi) tadi sama dengan banyak kali A dan B bersama-sama terjadi dalam $n$ usaha, sehingga:

$$
\left(\begin{array}{c}
\text { Frekwensi } \\
\text { relatif A dalam } \\
\text { usaha saat B terjadi }
\end{array}\right)=\frac{n(A B)}{n(B)}
$$

Ini yang dinamakan frekwensi relatif bersyarat $A$ diketahui $B$ yang dinyatakan dengan $R(A / B)$. Terlihat bahwa :

$$
R(A / B)=\frac{n(A B)}{n(B)}=\frac{n(A B) / n}{n(B) / n}=\frac{R(A B)}{R(B)}
$$

Bila $\mathrm{n}$ membesar maka frekwensi relatif mendekati peluang yang sesungguhnya.

\subsection{Statistik Bayes}

Jika terdapat dua konstruksi statistik, katakan $\mathrm{U}$ dan $\mathrm{V}$, dimana $\mathrm{U}<\mathrm{V}$, sedemikian hingga kita mempunyai peluang sebelumnya $\mathrm{p}$ yang ada variabel random $(\mathrm{U}, \mathrm{V})$ yang tetap tetapi titiknya tidak diketahui (parameter). Prinsip ini dapat diadopsi dengan menggunakan hasil berdasarkan percobaan untuk menghitung nilai dari $\mathrm{U}$ dan $\mathrm{V}$, yaitu u dan $\mathrm{v}$, kemudian dilakukan peninjauan kembali interval (u,v) yakni 100\% interval keyakinan untuk parameter. Pengadopsian prinsip ini merupakan salah satu metode pendugaan interval.

Misalkan variabel random $X$ mempunyai distribusi peluang yang bergantung pada simbol $\Theta$, dimana $\Theta$ suatu elemen dari himpunan $\Omega$, masalah pendugaan interval dimasukkan kedalam hitungan terdahulu dari ekperimen statistik dan diaplikasikan dalam prinsip statistik inferensi (statistical inference) yang disebut Statistik Bayes (Bayesian Statistics).

Jika simbol $\Theta$ adalah rata-rata dari distribusi dan $\Omega$ merupakan garis real. $\Theta$ suatu konstanta, walaupun konstanta tersebut tidak diketahui. Misalkan sekarang diperkenalkan variabel random $\varnothing$ yang berdistribusi peluang pada himpunan $\Omega$; dan terlihat diatas $\mathrm{x}$ sebagai suatu nilai yang mungkin dari variabel random $\mathrm{X}$, terlihat diatas $\Theta$ adalah nilai yang mungkin dari variabel random $\varnothing$. Maka distribusi dari X bergantung pada $\Theta$ diatas, suatu determinasi random dari variabel random $\varnothing$. Perlu dicatat pdf dari $\varnothing$ oleh $\mathrm{h}(\Theta)=0$, bila $\Theta$ adalah suatu elemen dari $\Omega$.

Misalkan $\mathrm{X}_{1}, \mathrm{X}_{2}, \ldots \ldots, \mathrm{X}_{\mathrm{n}}$ menyatakan sampel random dari distribusi $\mathrm{X}$ dan misalkan $Y$ menyatakan suatu statistik yang merupakan fungsi dari $X_{1}, X_{2}, \ldots \ldots, X_{n}$. Maka dapat ditentukan pdf dari $\mathrm{Y}$ untuk setiap $\Theta$ yang diberikan, yang mana dapat dicari pdf bersyarat dari $Y$, memberikan $\varnothing=\Theta$, yang dinyatakan oleh $g(y \mid \Theta)$. Maka pdf gabungan dari $Y$ dan $\varnothing$ adalah:

$$
k(\Theta, y)=h(\Theta) g(y \mid \Theta)
$$

Jika $\varnothing$ adalah variabel random tipe kontinu, pdf marginal dari Y adalah :

$$
k_{1}(y)=\int_{-\infty}^{\infty} h(\theta) g(y \mid \theta) d \theta
$$


Jika $\varnothing$ adalah variabel random dari tipe diskrit, integrasi akan diganti oleh jumlahan. Dalam hal ini pdf bersyarat dari $\varnothing$ diberikan $\mathrm{Y}=\mathrm{y}$, adalah:

$$
k(\theta \mid y)=\frac{k(y, \theta)}{k(y)}=\frac{h(\theta) g(y \mid \theta)}{k_{1}(y)}, \quad k_{1}(y)>0
$$

Ini merupakan salah satu bentuk dari rumus Bayes.

Dalam statistik Bayes pdf $h(\Theta)$ disebut pdf prior dari $\varnothing$ dan pdf bersyarat $\mathrm{k}(\Theta \mid \mathrm{y})$ disebut pdf posterior dari $\varnothing$. Hal ini merupakan akibat dari $\mathrm{h}(\Theta)$ adalah pdf dari prior $\varnothing$ untuk observasi $\mathrm{Y}$, dimana $\mathrm{k}(\Theta \mid \mathrm{y})$ adalah pdf dari $\varnothing$ sesudah observasi $\mathrm{Y}$ dibuat.

\section{Jika kita ingin menduga titik $\Theta$ :}

Dari bentuk Bayes, nyata pemilihan fungsi keputusan w yaitu w(y) adalah nilai dugaan dari $\Theta$ ( suatu nilai eksperimental dari variabel random $\varnothing$ ) dimana kedua nilai y dihitung dan pdf bersyarat $\mathrm{k}(\Theta \mid \mathrm{y})$ diketahui. Pemilihan fungsi keputusan bergantung pada fungsi $£[\Theta, w(y)]$. Satu cara dalam hal ini bergantung pada fungsi kerugian dapat direfleksikan dalam memilih fungsi keputusan w sebagai cara pendugaan bersyarat dari kerugian minimum penyelesaian Bayes A yang adalah fungsi keputusan minimalis :

$$
E\{L[\phi, w(y)] \mid Y=y\}=\int_{-\infty}^{\infty} L[\theta, w(y)] k(\theta \mid y) d \theta
$$

jika $\varnothing$ adalah variabel random tipe kontinu. Biasanya modifikasi anggota sisi kanan variabel random pada persamaan dibuat untuk tipe diskrit.

Dugaan bersyarat $Y=y$, menandakan variabel random suatu fungsi dari statistik $Y$. Nilai harapan fungsi $Y$ dinotasikan sebagai :

$$
\int_{-\infty}^{\infty}\left\{\int_{-\infty}^{\infty} L[\theta, w(y)] k(\theta \mid y) d \theta\right\} k_{1}(y) d y=\int_{-\infty}^{\infty}\left\{\int_{-\infty}^{\infty} L[\theta, w(y)] g(y \mid \theta) d y\right\} h(\theta) d \theta,
$$

dalam hal kontinu. Integral didalam kurung yang terakhir untuk setiap $\Theta \in \Omega$, fungsi beresiko $R(\theta, w)$; sesuai ekspresi terakhir adalah nilai rata-rata beresiko, atau dugaan beresiko. Karenanya, minimalis penyelesaian Bayes :

$$
\int_{-\infty}^{\infty} L[\theta, w(y)] k(\theta \mid y) d \theta
$$

untuk setiap $y$, dimana $k(y)>0$, yang adalah jelas merupakan penyelesaian Bayes $w(y)$ minimalis nilai rata-rata yang beresiko.

\subsection{Ketidaksamaan Cramer-Rao}

Ketidaksamaan Cramer-Rao sebagai karya dari Cramer tahun 1946 dan karya Rao tahun 1945, walaupun sebenarnya pertama kali diperkenalkan oleh M. Frechet tahun 1937-1938 dalam bahasa Prancis.

Jika berhadapan dengan peubah acak $X_{1}, X_{2}, \ldots \ldots, X_{\mathrm{n}}$ yang bebas masing-masing dengan f.d. $F(x \mid \theta)$ yang sama dari peubah acak $X$, yang dianggap bahwa nilai apa yang disebut dengan "kasus penaksiran teratur", yakni bahwa $F(x \mid \theta)$ dan setiap penaksir $t_{\mathrm{n}}$ yang akan ditangani memenuhi syarat teknis tertentu. Yang mana syarat-syarat ini bersifat tidak biasanya dipenuhi jika himpunan kemungkinan nilai dari peubah acak $X$ tergantung pada nilai parameter $\theta$ yang tidak diketahui. 
Teorema : Ketidaksaman Cramer-Rao

Dalam kasus penaksiran teratur, andaikan $X_{1}, X_{2}, \ldots \ldots, X_{\mathrm{n}}$ peubah acak bebas masing-masing dengan f.p.p. $f(x \mid \theta)$ (masing-masing dengan fungsi peluang titik $f(x \mid \theta)$. Andaikan $t_{\mathrm{n}}\left(X_{1}, X_{2}, \ldots, X_{\mathrm{n}}\right)$ suatu penaksir dari suatu fungsi dari $\theta$, katakanlah $g(\theta)$, dan andaikan $b_{\mathrm{n}}(\Theta)$ bias dari $t_{\mathrm{n}}: b_{\mathrm{n}}(\theta)=E\left(t_{\mathrm{n}}\right)-g(\theta)$. Maka berlaku hal-hal berikut ini:

1. Ketidaksamaan Cramer-Rao untuk fungsi dari $\theta$

$$
E_{\theta}\left(t_{n}-g(\theta)\right)^{2} \geq \frac{\left(g^{\prime}(\theta)+b_{n}^{\prime}(\theta)\right)^{2}}{n I(\theta)}
$$

2. Ketidaksamaan Cramer-Rao untuk penaksir tak bias dari fungsi $\Theta$.

Jika $t_{\mathrm{n}}$ suatu penaksir tak bias dari $g(\theta)$, kita peroleh

$$
\operatorname{Var}_{\theta}\left(t_{n}\right) \geq \frac{\left(g^{\prime}(\theta)\right)^{2}}{n I(\theta)}
$$

3. Ketidaksamaan Cramer-Rao untuk penaksir tak bias $\Theta$.

Jika $t_{\mathrm{n}}$ suatu penaksir tak bias dari $\theta$, kita peroleh

$$
\begin{aligned}
k(\theta \mid y) & =\frac{k(y, \theta)}{k(y)}=\frac{h(\theta) g(y \mid \theta)}{k_{1}(y)}, \\
\operatorname{Var}_{\theta}\left(t_{n}\right) & \geq \frac{1}{n I(\theta)}
\end{aligned}
$$

Bukti :

Berdasarkan definisi bias dari $t_{\mathrm{n}}$ sebagai penaksir $g(\theta)$, diperoleh

$$
g(\theta)+b_{n}(\theta)=E_{\theta}\left(t_{n}\right)=\int_{-\infty}^{\infty} \ldots . . \int_{-\infty}^{\infty} t_{n}\left(x_{1}, \ldots ., x_{n}\right)\left(\prod_{i=1}^{n} f\left(x_{i} \mid \theta\right)\right) d x_{1} \ldots . . d x_{n},
$$

dan diturunkan terhadap $\theta$ maka diperoleh :

$$
\begin{aligned}
g^{\prime}(\theta)+b_{n}^{\prime}(\theta) & =\int_{-\infty}^{\infty} \ldots . . \int_{-\infty}^{\infty} t_{n}\left(x_{1}, \ldots, x_{n}\right)\left(\frac{\partial}{\partial \theta} \prod_{i=1}^{n} f\left(x_{i} \mid \theta\right)\right) d x_{1} \ldots . . d x_{n} \\
& =\int_{-\infty}^{\infty} \ldots . . \int_{-\infty}^{\infty} t_{n}\left(x_{1}, \ldots ., x_{n}\right)\left(\frac{\partial}{\partial \theta} \ln \left(\prod_{i=1}^{n} f\left(x_{i} \mid \theta\right)\right)\right)\left(\prod_{i=1}^{n} f\left(x_{i} \mid \theta\right)\right) d x_{1} \ldots . . d x_{n} \\
& =\int_{-\infty}^{\infty} \ldots . \int_{-\infty}^{\infty}\left(t_{n}-g(\theta)\right)\left(\frac{\partial}{\partial \theta} \ln \left(\prod_{i=1}^{n} f\left(x_{i} \mid \theta\right)\right)\right)\left(\prod_{i=1}^{n} f\left(x_{i} \mid \theta\right)\right) d x_{1} \ldots . . d x_{n}
\end{aligned}
$$


Disini telah dimasukkan $g(\theta)$ karena integralnya nol sebab

$$
\begin{aligned}
& \int_{-\infty}^{\infty} \ldots \int_{-\infty}^{\infty} g(\theta)\left(\frac{\partial}{\partial \theta} \ln \left(\prod_{i=1}^{n} f\left(x_{i} \mid \theta\right)\right)\right)\left(\prod_{i=1}^{n} f\left(x_{i} \mid \theta\right)\right) d x_{1} \ldots . d x_{n} \\
= & g(\theta) \int_{-\infty}^{\infty} \ldots . \int_{-\infty}^{\infty} \frac{\partial}{\partial \theta}\left(\prod_{i=1}^{n} f\left(x_{i} \mid \theta\right)\right) d x_{1} \ldots . d x_{n} \\
= & g(\theta) \frac{\partial}{\partial \theta} \int_{-\infty}^{\infty} \ldots . . \int_{-\infty}^{\infty} f\left(x_{1} \mid \theta\right) \ldots . f\left(x_{n} \mid \theta\right) d x_{1} \ldots . d x_{n}=g(\theta) \frac{\partial}{\partial \theta}(1)=0
\end{aligned}
$$

Susun kembali persaman (1) diatas, maka diperoleh

$$
\begin{aligned}
g^{\prime}(\theta)+b^{\prime}{ }_{n}(\theta) & =E_{\theta}\left(\left(t_{n}-g(\theta)\right)\left(\frac{\partial}{\partial \theta} \ln \prod_{i=1}^{n} f\left(X_{i} \mid \theta\right)\right)\right) \\
& \leq\left(E_{\theta}\left(t_{n}\left(X_{1} \ldots X_{n}\right)-g(\theta)\right)^{2}\right)^{0,5} x\left(E_{0}\left(\frac{\partial}{\partial \theta} \ln \prod_{i=1}^{n} f\left(X_{i} \mid \theta\right)^{2}\right)^{0,5}\right.
\end{aligned}
$$

Dengan jalan yang sama diperoleh :

$$
-g^{\prime}(\theta)-b_{n}^{\prime}(\theta)=E_{0}\left(\left(g(\theta)-t_{n}\right)\left(\frac{\partial}{\partial \theta} \ln \prod_{i=1}^{n} f\left(X_{i} \mid \theta\right)\right)\right)
$$

memiliki batas atas yang sama ( $\operatorname{karena} E(Z)^{2}=E(-Z)^{2}$ untuk $Z=t_{n}-g(\theta)$ ), sehingga :

$$
\left|g^{\prime}(\theta)+b_{n}^{\prime}(\theta)\right| \leq\left(E_{\theta}\left(t_{n}\left(X_{1}, \ldots, X_{n}\right)-g(\theta)\right)^{2}\right)^{0,5}(n I(\theta))^{0,5}
$$

Disini diperoleh bentuk paling umum dari teorema ini dengan menguadratkan tiap sisi kemudian membaginya dengan $n I(\theta)$. Jika $t_{\mathrm{n}}$ tak bias, $b_{\mathrm{n}}=0$ ( jadi $\left.\mathrm{b}_{\mathrm{n}}=0\right)$, dan $E_{\Theta}\left(t_{\mathrm{n}}-\mathrm{g}(\Theta)\right)^{2}=\operatorname{Var} \Theta\left(t_{\mathrm{n}}\right)$, maka bentuk 2 dari teorema telah terbukti. Akhirnya, jika $g(\Theta)=\Theta$ maka $g(\Theta)^{\prime}=1$ dan bentuk $\mathbf{3}$ dari teorema terbukti.

\section{Daftar Pustaka}

[1] E.J. Dudewicz , S.N. Mishra, 1988,"Modern Mathematical Statistics”, by John Wiley \& Sons, Ltd. Inc

[2] Hogg and Craig, 1995, "Introduction to Mathematical Statistics", Printice Hall, fifth edition. 
